\title{
THE EXISTENCE OF ADAT LAND POST-ENACTMENT OF LAW NUMBER 6 YEAR 2014 ON VILLAGE ${ }^{\Omega}$
}

\author{
Sri Hajati, Sri Winarsi and Oemar Moechthar \\ Faculty of Law, Universitas Airlangga Surabaya \\ E-mail: sri.hajati.unair@gmail.com
}

\begin{abstract}
Post-Enactment of Law No. 6 Year 2014 on village, a village is divided into two: villages and adat villages. Adat village may have adat land assets. The law will not be explained in more detail, in addition to the Regulation of the State Minister of Agrarian/Head of National Land Agency No. 5 Year 1999 which was repealed in 2015 resulting in a legal vacuum in the regulation of traditional dispute resolution. This research apllied statute and conceptual approach while the analysis was conducted qualitatively, by pointing to the principles and procedural law as well as analyzing the various factors of social, economic and political process and procedural subtantive resolution of cases. The causal factors do not explain the existence of adat land which is not accommodated by local regulations as an obligation for local governments to undertake research and data collection ulayat lands in their area, as mandated by Law Number 23 Year 2014 which was confirmed by Regulation Number 38 Year 2007 and Law Number 6 Year 2014.
\end{abstract}

Keywords: village government, ulayat land rights, society

\section{Abstrak}

Pasca Berlakunya UU Nomor 6 Tahun 2014 tentang Desa, desa dibagi menjadi dua yakni desa dan desa adat. Desa adat dapat memiliki aset berupa tanah adat. Tanah adat dalam UU tersebut belum dijelaskan lebih rinci, disamping itu Peraturan Menteri Negara Agraria Nomor 5 Tahun 1999 telah dicabut tahun 2015, sehingga terjadi kekosongan hukum dalam pengaturan penyelesaian sengketa adat. Metode yang digunakan adalah metode pendekatan perundang-undangan dan pende-katan konsep, analisis dilakukan secara kualitatif, dengan mengetengahkan prinsip-prinsip dan prosedural hukum serta menganalisis berbagai faktor-faktor sosial, ekonomi dan politik dalam proses prosedural dan subtansif penyelesaian kasus. Faktor penyebab belum jelasnya eksistensi tanah adat adalah belum tersosialisasikan peraturan daerah yang merupakan kewajiban bagi pemerintah daerah untuk melakukan penelitian dan pendataan tanah-tanah ulayat yang ada di wilayahnya, seperti yang diamanatkan oleh UU Nomor 23 Tahun 2014 yang dikukuhkan oleh PP Nomor 38 Tahun 2007 serta UU Nomor 6 Tahun 2014.

Kata kunci: pemerintahan desa, hak ulayat, masyarakat hukum adat

\section{Introduction}

Indonesia as a unitary state based on the principles of decentralization provides an opportunity and freedom to the regions to organize local autonomy. Local Autonomy as a response to the demand for the changing of centralized state policy pattern and authoritarian government is expected to empower the local

$\Omega$ Competence Grants Research, Letter of the Assignment Agreement Implementation of the Research Program Number: 018/SP2H/LT/DRPM/II/2016, Ruislag Tanah Adat Sebagai Model Pelestarian dan Pemberdayaan Masyarakat Adat, February $17^{\text {th }} 2016$ optimally. The main autonomy principles includes: first, implementation of the local autonomy is to respect democracy, justice, equity and the potential and diversity of the regions; second, the implementation of local autonomy is based on broad, real, and responsible autonomy; third, the implementation of local autonomy should further enhance the autonomy the autonomous region; fourth, the implementation of local autonomy should enhance the role and function of the local legislature, both function of budget and organization of government. It can be said that the spirit of local autonomy 
is to build the local autonomy and enhance its democratic life in society. ${ }^{1}$

Efendi Berutu said that the word government may be defined in either broader or narrower sense. In broader sense, it means the entire functions of the state such as the legislative, executive and judicial body. While the government in the narrower sense refers to the executive body only. ${ }^{2}$ Since 1998 reform, There is a demand to implement the local autonomy namely a freedom of local government (dicretionary power) to govern itself based on innovation, creativity and society's active role in developing the region, ${ }^{3}$ including village government.

After Indonesia independence, the position of village as an autonomous entity was retained. It can be seen by placing village as a level III of region based on Law Number 22 Year 1948 on the Establishment of the Basic Rules Regarding Self-Governing Regions which are entitled to organize and manage their domestic affairs. ${ }^{4}$ Village government is an operation of government affairs and public interests in the governance system of the Republic of Indonesia. Village Administration is a subsystem within the national systems of governance so that the village has the authority to regulate and manage the social interests. The rationale basics are diversity, participation, real autonomy and empowerment.

$\Omega$ Competence Grants Research, Letter of the Assignment Agreement Implementation of the Research Program Number: 018/SP2H/LT/DRPM/II/2016, Ruislag Tanah Adat Sebagai Model Pelestarian dan Pemberdayaan Masyarakat Adat, February $17^{\text {th }} 2016$

1 Dody Eko Wijayanto, "Kepala Desa Dengan Badan Permusyawaratan Desa Dalam Pembentukan Peraturan Desa", Jurnal Independent, Vol. 2 No. 1, Lubuklinggau: PT. Airgading Putra Media, page 41.

2 Efendi Berutu in Nomensen Sinamo, 2010, Hukum Pemerintahan Daerah di Indonesia, Jakarta: Pustaka Mandiri, page 1; see at Yusnani Hasjimzoem, "Dinamika Hukum Pemerintahan Desa”, Fiat Justisia Jurnal IImu Hukum, Vol. 8 No. 3, July-September 2014, Bandar Lampung: Faculty of Law Universitas Lampung, page 465.

3 Sri Soemantri Martosoewignjo, 1992, Bunga Rampai Hukum Tata Negara Indonesia, Bandung: Alumni, page 33, in Yusnani Hasjimzoem, Loc.cit.

4 Agus Kusnadi, "Perkembangan Politik Hukum Pemerintahan Desa Menurut Undang-Undang Nomor 32 Tahun 2004 tentang Pemerintahan Daerah dan Undang-Undang Nomor 6 Tahun 2014 tentang Desa", Padjajaran Jurnal Ilmu Hukum, Vol. 2 No. 3 of 2015, Bandung: Faculty of Law Universitas Padjajaran, page 566.
Village is a legal community unit which limitedly regulates and manages the affairs of government, the public interest, origin and/or adat rights recognized and respected in the governance system of the Unitary State of the Republic of Indonesia. The existence of the village in terms of territorial aspects of a region has existed long before the Unitary State of the Republic of Indonesia was formed. At present, 73,000 (seventy three thousand) villages (desa) and about 8,000 (eight thousand) villages (kelurahan) are identified. ${ }^{5}$ Therefore, its existence shall be appreciated and given a survival assurance in Unitary State of the Republic of Indonesia.

Village is an autonomous institution with the legal traditions and customs and relatively independent. Regulations on the village government is formulated in line with regulations governing state administration of Indonesia. Regulations on Local Government or Local Autonomy are provided in Law Number 32 Year 2004 previously regulated in Law Number 22 Year 1999 concerning on Local Government and in the New Order period stipulated in Law No. 5 of 1979.6 The provisions concerning the autonomy also have an impact on the village autonomy which is now regulated by Law Number 6 Year 2014 that it is led by a village head.

Under the provisions of Article 76 of Law Number 6 Year 2014, it stated that the assets of Villages may be a village treasury land, adat land (ulayat), the village market, animal market, boat moorings, village buildings, fish auction, agricultural auction, village forests, the spring property of the village, public baths and other assets belonging to the Village. Land is considered as one of the eternal and permanent treasures to be invested for future since the existence of the land itself lasts more than human life. In fact, the community recognize a right of eigendom, right of Opstal, right of erfpacht and right of people or bumiputera who is subject to the adat law which is unwritten belongs to the

Explanation of Law Number 6 Year 2014.

See Afriniko, "Politik Hukum Otonomi Desa Berdasarkan Undang-Undang Nomor 6 Tahun 2014 tentang Desa", Jurnal Online Mahasiswa Fakultas Hukum, Vol. 2 No. 2 October 2015, Bandar Lampung: Faculty of Law Universitas Lampung, page 4 . 
local people. It is often called as the adat land e.g. ulayat land right, Yasan land, Gogolan Land and the other land. ${ }^{7}$

Therefore, human has put the land as a thing that always gets special attention and management as well as human efforts to ensure land tenure. The basic philosophy that must be understood when we talk about land as adat rights is about the relationship between people and the land. This is closely related to kinship, power, leadership, livelihoods, rites and spiritual realm often called as 'religio magical' relation. This makes the land is considered as an integral part of the one's personality. There is a forceful bond to the land but it does not mean sacred. Rather, human spiritual relation with the land is holy. ${ }^{8}$ Recognizing the importance of the function of land, consequently, the government shall improve processing, setting and maintenance of land as the source for the welfare and prosperity in accordance with the provisions of the given government legislation.

The land itself has previlege status in people's life until present. Many Indonesian people consider land as a symbol of social status. According to them, land is a socio-cultural root and be a symbol of self-existence so the value of land is more than just the price of a commodity. ${ }^{9}$ In reform era, many local governments massively exploit land or forests and provide the license or concession to private companies to utilize the areas in order to generate the income needed by the local governments. ${ }^{10}$

7 Ulfia Hasanah, "Status Kepemilikan Tanah Hasil Konversi Hak Barat Berdasarkan UU No. 5 Tahun 1960 tentang Peraturan Dasar Pokok-Pokok Agraria Dihubungkan dengan PP No. 24 tahun 1997 tentang Pendaftaran Tanah", Jurnal Ilmu Hukum, Vol. 3 No. 1, Pekanbaru: Faculty of Law Universitas Riau, page 3.

8 see Andreas Jefri Deda, et.al. "Masyarakat Hukum Adat dan Hak Ulayat Di Provinsi Papua Barat Sebagai Orang Asli Papua Di Tinjau Dari Sisi Adat Dan Budaya; Sebuah Kajian Etnografi Kekinian”, Jurnal Administrasi Publik, Vol. 11 No. 2, October 2014, Malang: Universitas Brawijaya, page 17.

9 Bernhard Limbong, 2012, Konflik Pertanahan, Jakarta: Magaretha Pustaka, page 1 in Iswantoro, "Implementasi Program Layanan Rakyat untuk Sertifikat Tanah (LARA SITA) Terhadap Tanah di Kabupaten Sleman dalam Rangka Kepastian Hukum Perspektif Undang-Undang Nomor 24 Tahun 1997 tentang Pendaftaran Tanah", Jurnal Panggung Hukum, Vol. 1 No. 1, January 2015, Jakarta: AIFIS, page 28-29.

10 Afifah Kusumadara, "Perkembangan Hak Negara Atas Tanah: Hak Menguasai Atau Hak Memiliki?”, Jurnal Me-
The Word Commission on the Social Dimension of Globalization formed by International Labour Organization (ILO) in February 2012 in their report entitled "a Fair Globalization: Creating Opportunities for All", noting that the activities of the mining industry have a negative impact on local people even the environment in which they interact. ${ }^{11}$

Post-enactment of Law Number 6 Year 2014, the existence of adat land is still not clearly regulated which results in the vacuum of law. Besides, the removal of Minister Regulation of Agriculture Number 5 Year 1999 on Guidelines for Problem Solving of Ulayat Rights of Adat People by the provisions of the Minister of Agrarian and Spatial Planning/Head of National Land Agency Regulation Number 9 Year 2015 was repealed by the Regulation of Minister of Agrarian and Spatial Planning/Head of National Land Agency Number 10 Number 2016 concerning Procedures for Determining the Communal Land Rights of Adat People and Communities in Particular Area.

\section{Problems}

In regards to the description, this paper seeks to analyze issues related to the existence of Adat Land as one of the village assets after the enactment of Law Number 6 Year 2014 on village.

\section{Research Method}

This research is legal research which may provide an input on setting up and management of adat land (ulayat land) in village administration according to Law Number 6 Year 2014. The approach is legislation which focused on the rules and regulations to analyze hierarchical relationships, consistency and compatibility between Law Number 6 Year 2014 concerning the village with other rules of law. This study also uses conceptual approaches made by reviewing and analyzing the concepts and theories about

dia Hukum, Vol. 20 No. 2, December 2013, Yogyakarta: Faculty of Law Universitas Muhammadiyah Yogyakarta, page 272 .

11 Muazzin, "Hak Masyarakat Adat (Peoples) atas Sumber Daya Alam: Perspektif Hukum Internasional”, Padjajaran Jurnal Ilmu Hukum, Vol. 1 No. 2 of 2014, Bandung: Faculty of Law Universitas Padjajaran, page 324-325. 
local government, village government, asset area or village associated with the land position of the village treasury as a source of village income properly managed for welfare of rural communities. In addition, this study also conducted case study approach to analyze and assess the issue-related cases. To analyze the data qualitatively either by pointing to the principles of law (such as the legal principles of legislation) or the requisite procedural law was conducted as well as to analyze the various factors of social, economic and political in the process which affects the procedural and substansive case settlement of adat lands.

\section{Discussion}

Definition of adat law society by Ter Haar, is: "groups of constant and organized society that have its own power, both tangible and intangible". ${ }^{12}$ World Bank prepared a number of criteria for adat groups: ${ }^{13}$ first, have close relations with the region descendants and natural resources in the region; second, determine the identity and identified by others as members of a distinct cultural group; third, have a native language that is often different from the national language; fourth, have the adat structures in the social and political; and fifth, production is mainly oriented subsystem.

Firsty Husbani said that communities have their own adat laws. In terms of management of natural resources, they have a variety of policies to fit in their life philosophy. For example, the concept of adat land rights, basically, adat rights is a guideline in the management of natural resources, how the authority communities should organize and plan the use of natural resources, establish legal relations of its members with resources and take care of issues related to the utilization of resources by outsiders. ${ }^{14}$

12 Hilman Hadikusuma, 2003, Pengantar Hukum Adat Indonesia, Bandung: Mandar Maju, page 105.

13 Irene Mariane, 2014, Kearifan Lokal Pengelolaan Hutan Adat, Cet. I, Jakarta: RajaGrafindo Persada, page 11.

14 Firsty Husbani, "Kajian Atas Pengakuan Hak dan Eksistensi Masyarakat Adat dalam Pengelolaan Sumber Daya Alam dalam Peraturan Perundang-Undangan Lingkungan Hidup di Indonesia”, Jurnal Hukum Lingkungan, Vol. 4, 1997, Jakarta: Indonesian Center for Environmental Law, page 88 .
Generally, people call adat land by two senses: first, the land " Former property rights of " including Girik, Petok, Rincik, Ketitir Land derived from adat lands or other lands that have not been converted into one land with certain rights (HM, HGU, HGB, HP) and has not been registered (certified) at the local land Office; and second, privately owned land (adat) communities of adat law: Titian Land, Watering Land, treasury land village, tanah bengkok and others.

Adat rights (beschikkingsrecht) is a legal partnership rights for land and is not individual rights. ${ }^{15}$ In General Explanation II item 3 of Article 3 of adat rights known by the national agrarian law comprises two terms. Terms of Existence (existence), adat rights which are recognized as long as the fact exists. Adat rights must not contradict with the Law and the higher legislation, yet, it is eliminated since adat right is fully enforced by local adat law.

Through the government's political law, the rights of adat communities degraded as a result of the insistence of government policies that only look land for economic aspect only. Even in certain circles adat and traditional laws actually are afraid as a danger or threat of democratic civilization and human values. ${ }^{16}$ Accordingly, it needs to be balanced by law populist politics through the empowerment of autonomy (the inventory of existing public rights), in the future the village is necessary to be subject of management rights. ${ }^{17}$

\section{Adat Land and Law concerning Local Govern- ment}

In the provisions of Law Number 23 Year 2014 concerning Local Government division of government affairs in the land sector especially

15 Eddy Ruchiyat, 1984, Sampai Orde Baru, Bandung: Alumni, page 33.

16 See Husen Alting, "Penguasaan Tanah Masyarakat Hukum Adat (Suatu Kajian Terhadap Masyarakat Hukum Adat Ternate)", Jurnal Dinamika Hukum, Vol. 11 No. 1, Januari 2011, Purwokerto: Faculty of Law Universitas Jenderal Soedirman, page 92-93.

17 See Elita Rahmi, "Eksistensi Hak Pengelolaan Atas Tanah (HPL) dan Realitas Pembangunan Indonesia", Jurnal Dinamika Hukum, Vol. 10 No. 3, September 2010, Purwokerto: Faculty of Law Universitas Jenderal Soedirman, page 352 . 
related to adat land, the central government has no authority in determining the adat land. While the Provincial Government and the Government of Regency/City has. As stated in the attachment of Law Number 23 Year 2014 letter
$\mathrm{J}$ related to concurrent governmental affairs division between the central government and the provincial and district/city (land sector), the table describes below:

\begin{tabular}{|c|c|c|c|c|}
\hline Number & SUB INTERESTS & CENTRAL GOVERNMENT & PROVINCE AREA & REGENCY/CITY AREA \\
\hline 1. & $\begin{array}{l}\text { Location } \\
\text { Permission }\end{array}$ & $\begin{array}{l}\text { Giving permission for loca- } \\
\text { tion across province areas. }\end{array}$ & $\begin{array}{l}\text { Giving permission for } \\
\text { location across re- } \\
\text { gency/ city areas in } 1 \\
\text { (one) province area. }\end{array}$ & $\begin{array}{l}\text { Giving permission for } \\
\text { location in } 1 \text { (one) re- } \\
\text { gency/city area }\end{array}$ \\
\hline 2. & $\begin{array}{l}\text { Land Procure- } \\
\text { ment for Public } \\
\text { Purposes }\end{array}$ & $\begin{array}{l}\text { Implementation of land } \\
\text { procurement for public } \\
\text { purposes }\end{array}$ & $\begin{array}{l}\text { Determining the loca- } \\
\text { tion of land procure- } \\
\text { ment for public pur- } \\
\text { poses of province }\end{array}$ & \\
\hline 3. & $\begin{array}{l}\text { Dispute over } \\
\text { working Land }\end{array}$ & $\begin{array}{l}\text { Solving a disputed of } \\
\text { working land across } \\
\text { province areas }\end{array}$ & $\begin{array}{l}\text { Solving a disputed of } \\
\text { working land across } \\
\text { residence/city areas } \\
\text { in } 1 \text { (one) province } \\
\text { area. }\end{array}$ & $\begin{array}{l}\text { Solving a disputed of } \\
\text { working land in resid- } \\
\text { ence/city area }\end{array}$ \\
\hline 4. & $\begin{array}{l}\text { Refund a loss } \\
\text { and charity } \\
\text { Land for devel- } \\
\text { opment }\end{array}$ & $\begin{array}{l}\text { Problem solving of Refund } \\
\text { a loss and charity Land for } \\
\text { development by central } \\
\text { government }\end{array}$ & $\begin{array}{l}\text { Problem solving of Re- } \\
\text { fund a loss and charity } \\
\text { Land for development } \\
\text { by province govern- } \\
\text { ment }\end{array}$ & $\begin{array}{l}\text { Problem solving of Re- } \\
\text { fund a loss and charity } \\
\text { Land for development by } \\
\text { residence/ city govern- } \\
\text { ment }\end{array}$ \\
\hline 5. & $\begin{array}{l}\text { Subject and } \\
\text { Object of Land } \\
\text { Redistribution } \\
\text { and the Max- } \\
\text { imum Excess } \\
\text { Land Restitu- } \\
\text { tion and Ab- } \\
\text { sentee Land }\end{array}$ & $\begin{array}{l}\text { Determining subject and } \\
\text { object of land redistribu- } \\
\text { tion and the maximum ex- } \\
\text { cess land restitution and } \\
\text { absentee land across } \\
\text { province government }\end{array}$ & $\begin{array}{l}\text { Determining subject } \\
\text { and object of land re- } \\
\text { distribution and the } \\
\text { maximum excess land } \\
\text { restitution and ab- } \\
\text { sentee land across res- } \\
\text { idence/city areas in } 1 \\
\text { (one) province. }\end{array}$ & $\begin{array}{l}\text { Determining subject and } \\
\text { object of land redistribu- } \\
\text { tion and the maximum } \\
\text { excess land restitution } \\
\text { and absentee land in re- } \\
\text { sidence/city areas }\end{array}$ \\
\hline 6. & Adat Land & & $\begin{array}{l}\text { Determining adat land } \\
\text { located across resid- } \\
\text { ence/ city area in } 1 \\
\text { (one) province }\end{array}$ & $\begin{array}{l}\text { Determining adat land } \\
\text { located in residence/city } \\
\text { area }\end{array}$ \\
\hline 7. & Vacant land & & 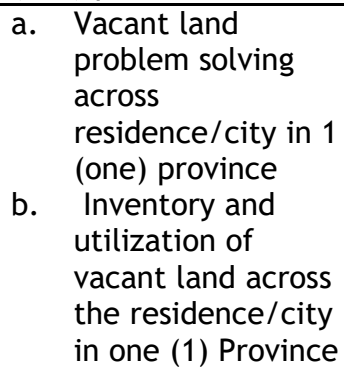 & $\begin{array}{ll}\text { a. } & \text { Problem solving } \\
\text { vacant land in the } \\
\text { residence/city } \\
\text { b. } \\
\text { b. Inventory and } \\
\text { utilization of vacant } \\
\text { land in the } \\
\text { residence/city }\end{array}$ \\
\hline 8. & $\begin{array}{l}\text { Opening permit } \\
\text { Land }\end{array}$ & & & $\begin{array}{l}\text { Publishing permission to } \\
\text { open ground }\end{array}$ \\
\hline 9. & Land Use & $\begin{array}{l}\text { Land use planning that } \\
\text { overlay cross Province }\end{array}$ & $\begin{array}{l}\text { Land use planning that } \\
\text { overlay cross } \\
\text { regency/city in (1) one } \\
\text { province }\end{array}$ & $\begin{array}{l}\text { Overlay land use } \\
\text { planning in the } \\
\text { residence/cities }\end{array}$ \\
\hline
\end{tabular}

In the Basic Agrarian Law recognized the term adat rights but until now the existence of adat rights still becomes an issue in the national land laws. Likewise, its status within communities themselves gives the existence of adat rights which some are still very strong but some other diminish even vanished. Based on the table above, those are not implemented by the central government but implemented by the provincial government and residence/ city governments. 


\section{Adat Land Position in Law Number 6 Year 2014}

In the history of the village supervision, some supervisions on the village have been set namely Law Number 22 Year 1948, Law Number 1 Year 1957, Law Number 18 Year 1965, Law Number 19 Year 1965, Law Number 5 Year 1974, Law Number 5 Year 1979, Law Number 22 Year 1999, Law Number 32 Year 2004 and Law Number 23 Year 2014. In the implementation, the regulation concerning the village cannot accommodate all the interests and needs of the village community, which until now numbered about 73,000 desa and about 8,000 kelurahan. Implementation arrangements of the village is so far applicable and no longer appropriate to the times especially regarding the position of adat law society, democratization, diversity, community participation, as well as progress and equitable development. It raises the gap between regions, poverty and social and cultural issues that can interfere integrity of the Unitary State of the Republic of Indonesia.

Law Number 6 Year 2014 prepared by the spirit of the constitutional mandate implementation, the arrangement of communities in accordance with the provisions of Article 18B paragraph (2) to be managed within the government structure in accordance with the provisions of Article 18 paragraph (7). The authority of adat law community unit on setting the adat rights refers to the provisions of the related sectoral legislation. By construction which combines the functions of a self-governing community with the local self-government, it is expected that adat law community unit which has been a part of the village is to be arranged into the Village and the Adat Village.

Adat village was originally known as the 'village' alone. However, when Dutch colonial established another village with a special task under government administration level, there was confusion about 'desa' definition. Therefore, to provide specific differentiation, the different villages functions and duties are named respectively 'adat village' and 'official village' or 'administrative villages'. ${ }^{18}$ The village and the Adat Village basically perform similar tasks; the only difference is in the implementation of the right of origin, especially regarding to social preservation of adat village, regulation and management of adat territories, the adat trial of peace, the maintenance of peace and order for the people of adat law, as well as setting the exercise of government based on the original order. Adat village functions as administration, finance village, village development, as well as facilitation and support received from the residence/ city government. In this position, the Village and the Adat Village receive equal treatment from the Government and Local Government.

The village has common characteristics in Indonesia while Adat Villages are different in terms of strong custom influences on the local government system, the management of local resources social and cultural life of the village. Adat Village in principle is a legacy organization of local community governance maintained for generations, still recognized and led by the leaders of adat villages in order to develop social welfare and local cultural identities. Adat Village with the right of origin is more dominant than that of village since the adat village was born as a native communities that exist in society. Adat Village is a traditional law community unit which historically have boundaries and cultural identity that is formed on the basis of territorial authorities to regulate and manage the interests of the village community based on origin right.

Therefore, as it develops, the Village and Adat Village can change into effective village governance, implementation of efficient development as well as community development in the region. In the same status as it was, the Village and the Adat Village are governed separately in Law Number 6 Year 2014.

18 See Adharinalti, "Eksistensi Hukum Adat dalam Penyelenggaraan Pemerintahan Desa di Bali", Jurnal Rechtsvinding, Vol. 1 No. 3, December 2012, Jakarta: Badan Pembinaan Hukum Nasional Kementerian Hukum dan HAM RI, page 412. 
In regards to adat land or communal land in the provisions of article 76 paragraph (1) of Law Number 6 Year 2014 concerning Village, it states that adat land is one of the village assets: "Village Assets can be land of the village treasury, communal land, the village market, animal market, mooring boats, building the village, the fish auction, the auction of agricultural, forest belongs to the village, the villageowned springs, public baths and other assets belonging to the village".

Criteria and determination consist of three elements namely the communities existence, adat rights and traditional legal order regarding the maintenance, control and use of adat land force and adhered to by the adat law communities. Research and determination of the adat rights of local government include experts adat law, adat law community in the regions concerned, NGOs and agencies that manage natural resources. The existence of adat lands of communities are still expressed in base map of land registration by affixing a sign of cartography and, where applicable, describing its limits and recording it in the land registry. Thus, the rules effectiveness on adat rights recognition depends on local government initiatives to conduct research as a basis for determining the existence of adat rights in the regions concerned by involving the concerning parties to assure results objectivity.

Regulation of the State Minister of Agrarian/ Head of National Land Agency Number 5 Year 1999 provides a very large portion to the local government as an autonomous region. Thus, needless to say, the local government residence/ city is the first line to protect adat rights. Through delegation of authority, there is an expectation to local government to manage land more effectively and efficiently as well as to balance the land dimension of economic and social functioning for better arrangement of the use and utilization of land.

\section{Conclusion}

Adat rights are recognized its existence in the national land law. The existence of adat rights in certain peoples can be seen on the daily activities of traditional elders and leaders as a duty bearer authority to regulate the acquisition and lead communal land use which is the land with the citizens adat law is concerned. Based on the research results, not all regions founded Local regulations specifically govern the protection of adat rights of the local people, either recognition, borders or legalization stewardship in communities. This is due to unheard local regulations which is an obligation for local governments to undertake research and data collection on lands in their area.

\section{Suggestion}

Local governments and village governments mainly adat villages need to establish local regulations for local government of residence/ city concerning the protection of adat rights of local communities as confirmed by the Government of the Adat Village with adat village regulations, including the determination of boundaries and territories. The local regulations can reduce their potential conflicts arising among governments, investors and local communities adat law which still has ownership rights.

\section{References}

Adharinalti. "Eksistensi Hukum Adat dalam Penyelenggaraan Pemerintahan Desa di Bali”. Jurnal Rechtsvinding. Vol. 1 No. 3. December 2012. Jakarta: Badan Pembinaan Hukum Nasional Kementerian Hukum dan HAM RI;

Afriniko. "Politik Hukum Otonomi Desa Berdasarkan Undang-Undang Nomor 6 Tahun 2014 tentang Desa". Jurnal Online Mahasiswa Fakultas Hukum. Vol. 2 No. 2. October 2015. Bandar Lampung: Faculty of Law Universitas Lampung;

Alting, Husen. "Penguasaan Tanah Masyarakat Hukum Adat (Suatu Kajian Terhadap Masyarakat Hukum Adat Ternate)". Jurnal Dinamika Hukum. Vol. 11 No. 1. January 2011. Purwokerto: Faculty of Law Universitas Jenderal Soedirman;

Deda, Andreas Jefri dan Suriel Semuel Mofu. "Masyarakat Hukum Adat Dan Hak Ulayat di Provinsi Papua Barat Sebagai Orang Asli Papua Di Tinjau Dari Sisi Adat Dan Buda- 
ya; Sebuah Kajian Etnografi Kekinian". Jurnal Administrasi Publik. Vol. 11 No. 2. October 2014. Malang: Universitas Brawijaya;

Hadikusuma, Hilman. 2003. Pengantar Hukum Adat Indonesia. Bandung: Mandar Maju;

Hasanah, Ulfia. "Status Kepemilikan Tanah Hasil Konversi Hak Barat Berdasarkan UU No. 5 Tahun 1960 tentang Peraturan Dasar Pokok-Pokok Agraria Dihubungkan dengan PP No. 24 tahun 1997 tentang Pendaftaran Tanah". Jurnal Ilmu Hukum. Vol. 3 No. 1. 2012. Pekanbaru: Faculty of Law Universitas Riau;

Hasjimzoem, Yusnani. "Dinamika Hukum Pemerintahan Desa". Fiat Justisia Jurnal Ilmu Hukum. Vol. 8 No. 3. July-September 2014. Bandar Lampung: Faculty of Law Universitas Lampung;

Husbani, Firsty. "Kajian Atas Pengakuan Hak dan Eksistensi Masyarakat Adat dalam Pengelolaan Sumber Daya Alam dalam Peraturan Perundang-Undangan Lingkungan Hidup di Indonesia". Jurnal Hukum Lingkungan. Vol. 4 No. 88. 1997. Jakarta: Indonesian Center for Environmental Law;

Iswantoro. “Implementasi Program Layanan Rakyat untuk Sertifikat Tanah (LARASITA) Terhadap Tanah di Kabupaten Sleman dalam Rangka Kepastian Hukum Perspektif Undang-Undang Nomor 24 Tahun 1997 tentang Pendaftaran Tanah". Jurnal Panggung Hukum. Vol. 1 No. 1. January 2015. Jakarta: AIFIS;

Kusnadi, Agus. "Perkembangan Politik Hukum Pemerintahan Desa Menurut Undang-Un- dang Nomor 32 Tahun 2004 tentan Pemerintahan Daerah dan Undang-Undang Nomor 6 Tahun 2014 tentang Desa". Padjajaran Jurnal Ilmu Hukum. Vol. 2 No. 3. 2015. Bandung: Faculty of Law Universitas Padjajaran;

Kusumadara, Afifah. "Perkembangan Hak Negara Atas Tanah: Hak Menguasai Atau Hak Memiliki?". Jurnal Media Hukum. Vol. 20 No. 2. December 2013. Yogyakarta: Faculty of Law Universitas Muhammadiyah Yogyakarta;

Limbong, Bernhard. 2012. Konflik Pertanahan. Jakarta: Magaretha Pustaka;

Mariane, Irene. 2014. Kearifan Lokal Pengelolaan Hutan adat. Cet. I. Jakarta: Raja Grafindo Persada;

Muazzin. "Hak Masyarakat Adat ( Peoples) atas Sumber Daya Alam: Perspektif Hukum Internasional". Padjajaran Jurnal Ilmu Hukum. Vol. 1 No. 2. 2014. Bandung: Faculty of Law Universitas Padjajaran;

Rahmi, Elita. "Eksistensi Hak Pengelolaan Atas Tanah (HPL) dan Realitas Pembangunan Indonesia". Jurnal Dinamika Hukum. Vol. 10 No. 3. September 2010. Purwokerto: Faculty of Law Universitas Jenderal Soedirman;

Ruchiyat, Eddy. 1984. Sampai Orde Baru. Bandung: Alumni;

Wijayanto, Dody Eko. "Kepala Desa Dengan Badan Permusyawaratan Desa Dalam Pembentukan Peraturan Desa". Jurnal Independent. Vol. 2 No. 1. Lubuklinggau: PT. Airgading Putra Media. 